\title{
Short term variation of marine organic aerosols under the North- western Pacific high pressure region in the summer of 1999
}

\author{
Mitsuo Uematsu, ${ }^{1 *}$ Kazutake Ohta, ${ }^{1,2}$ Kiyoshi Matsumoto ${ }^{1,2}$ and Itsushi Uno ${ }^{3}$ \\ ${ }^{1}$ Ocean Research Institute, University of Tokyo, Nakano-ku, Tokyo 164-8639, Japan \\ ${ }^{2}$ Japan Science and Technology Corporation, Core Research for Evolutional Science and Technology, \\ Kawaguchi 332-0012, Japan \\ ${ }^{3}$ Research Institute for Applied Mechanics, Kyushu University, Kasuga Park 6-1, Kasuga 816-8580, Japan
}

(Received October 16, 2000; Accepted December 4, 2000)

\begin{abstract}
To determine the variability of chemical properties in marine aerosols, a stationary shipboard measurement study was carried out at a station over the Northwest Pacific for 29 hours in the summer of 1999. Under a North Pacific high pressure system, carbonaceous substances, major inorganic ions, and particle numbers of typical marine aerosols were measured with little influence from continental and anthropogenic sources. The mass median diameter of organic aerosol was larger than $0.5 \mu \mathrm{m}$ and its behavior over time was similar to sea-salt aerosol. Although the source of marine organic aerosol was believed to be mainly from continents, this result suggested that organic substances in micro layer of the sea surface is one of the sources to supply fine organic aerosol to the marine atmosphere. The further investigation would be necessary over various oceanic regions to find out the effects of marine biological activities.
\end{abstract}

\section{INTRODUCTION}

Significant changes of chemical, physical and optical properties in aerosols are caused by anthropogenic perturbations. Anthropogenic sulfate aerosol was believed to behave as a major contributor for a negative radiative forcing to climate change (Charlson et al., 1991). Recently, other major chemical components in tropospheric aerosols including sea salt (Murphy et al., 1998), mineral dust (Sokolik and Toon, 1999), elemental carbon (Chylek et al., 1996), and organic carbon (Novakov and Penner, 1993) have been recognized as having the potential to affect radiative forcing (Takemura et al., 2000). Substantial portions of aerosols are produced by natural processes. Emission rates, concentrations and distribution patterns could be indirectly affected by regional and/or global climate change. Therefore, both natural and anthropogenic components in aerosols should be investigated for their characterization and variabil- ity in the troposphere (Matsumoto et al., 1998; Uematsu, 1998).

Among the major chemical components, organic aerosols are thought to be important for negative radiative forcing, much like sulfate aerosols (Rivera-Carpio et al., 1996; Matsumoto et al., 1997). This is because organic aerosols account for the large portion of total aerosol number density and behave as cloud condensation nuclei (CCN). The major sources of organic aerosols in marine atmosphere are industrial combustion and biomass burning derived from continents as determined by studies of the stable carbon isotopes (Cachier et al., 1986). Recently, it has been suggested that organic aerosols in marine atmosphere also may be associated with natural oceanic emissions (Novakov et al., 1997).

Under a project called Variability of Marine Aerosol Properties (VMAP), our objective is to determine the chemical composition of aerosols in the Asian outflow over the western North Pa-

*Corresponding author (e-mail: uematsu@ori.u-tokyo.ac.jp) 
cific region in different seasons and to understand the transport and transformation processes of the aerosols in the marine boundary layer (MBL). When the western North Pacific region is under the influence of the North Pacific high pressure in summer, the MBL is expected to have typical marine aerosols with minimal influences from the continental and anthropogenic sources. In this field study, we investigated the temporal variations of the chemical composition in the aerosols of the MBL over the western North Pacific during summer time. We attempted to determine the particle number density over several different particle size ranges and to characterize the major chemical compositions with high time resolution on the board R/V Tansei Maru during the KT9912 cruise in August, 1999.

\section{MEASUREMENTS}

Stationary measurements of marine aerosols at the station $\mathrm{JT}\left(34^{\circ} \mathrm{N}, 142^{\circ} \mathrm{E}, 270 \mathrm{~km}\right.$ southeast from Tokyo in Fig. 1) were carried out during the period from 0500 (JST: Japan Standard Time, UT +0900), 4 August through 1000, 5 August for 29 hours on board the ship. The ship's position was controlled to sample clean air from the bow. Under the stationary North Pacific high-pressure system, steady Easterly winds were blowing at 9-11 $\mathrm{m} \mathrm{s}^{-1}$ with scattered clouds at Station JT (Fig. 2). At 1700, 4 August, a very light shower was observed with no measurable of precipitation. It should be noted the sea surface temperature of the east oceanic region of the northern Japan was more than $1^{\circ} \mathrm{C}$ higher than the normal year during the summer of 1999 .

\section{Aerosol sampling on the ship board}

Mass concentrations of carbonaceous aerosols were measured hourly basis by using an ambient carbon particulate monitor (Rupprecht \& Patashnick Co. Inc., Series 5400). The sample air taken from the top deck at $1.0 \mathrm{~m}^{3} \mathrm{hr}^{-1}$ was introduced into the monitor after removing aerosols larger than $2.5 \mu \mathrm{m}$ in diameter by using a PM-2.5 Cyclone inlet. This particle cut off largely elimi-

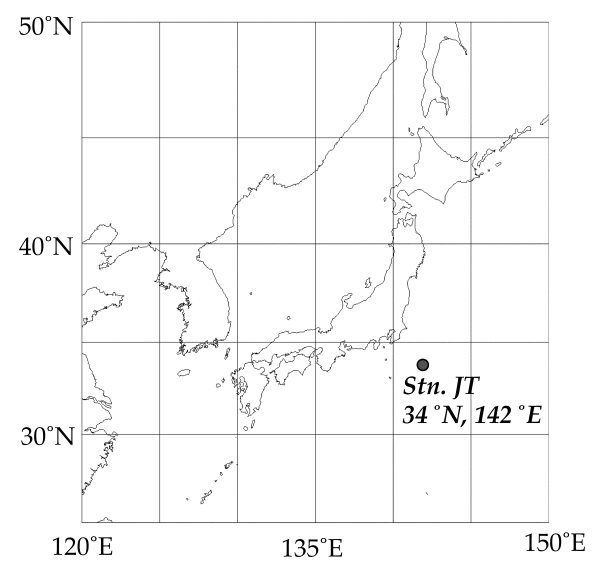

Fig. 1. Atmospheric sampling station JT during the KT99-12 cruise of the R/V Tansei Maru.

nates the disturbance caused by large mass of seasalt particles for the carbonaceous analysis. According to Hoffman and Duce (1977), the major mass of the organic carbon is on particles smaller than $1.0 \mu \mathrm{m}$ in diameter. Therefore the loss of total organic carbon will be minimal by the cutting off the particles by PM2.5. The monitor collected aerosols larger than $0.14 \mu \mathrm{m}$ on an impactor plate heated to $50^{\circ} \mathrm{C}$. The amount of volatile carbon at $340^{\circ} \mathrm{C}$ defined, as organic carbon was determined from the amount of $\mathrm{CO}_{2}$ produced in a $750^{\circ} \mathrm{C}$ afterburner. The residual material on the impactor plate was heated to $750^{\circ} \mathrm{C}$, and in this way the amount of the total carbon was determined. The $340^{\circ} \mathrm{C}$ default temperature was selected based on the thermogram of trade wind organic aerosol component which showed the concentration peak around $250^{\circ} \mathrm{C}$ and the sharp tail off up to $300^{\circ} \mathrm{C}$ (Novakov et al., 1997). It was agreed well with the $\mathrm{R} \& \mathrm{P}$ recommended default value. Elemental carbon evolves at temperature higher than $400^{\circ} \mathrm{C}$ (Gundel et al., 1984).

The difference in the concentration between the total carbon and the organic carbon was defined as the elemental carbon. The detection limit for one-hour sampling of OC and TC was 0.027 $\mu \mathrm{g} \mathrm{m}^{-3}$. Some of the elemental carbon concentrations were close to the detection limit with large uncertainty and therefore, the values for the el- 


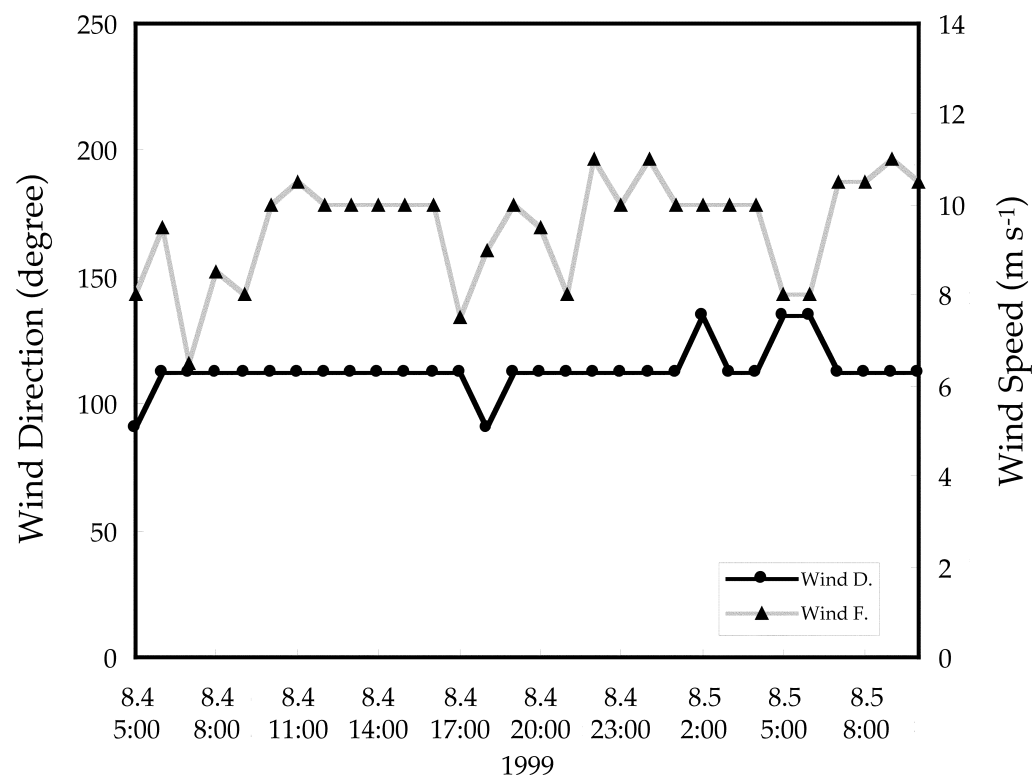

Fig. 2. Wind direction and wind speed at station JT during the atmospheric observations of 4 to 5 August.

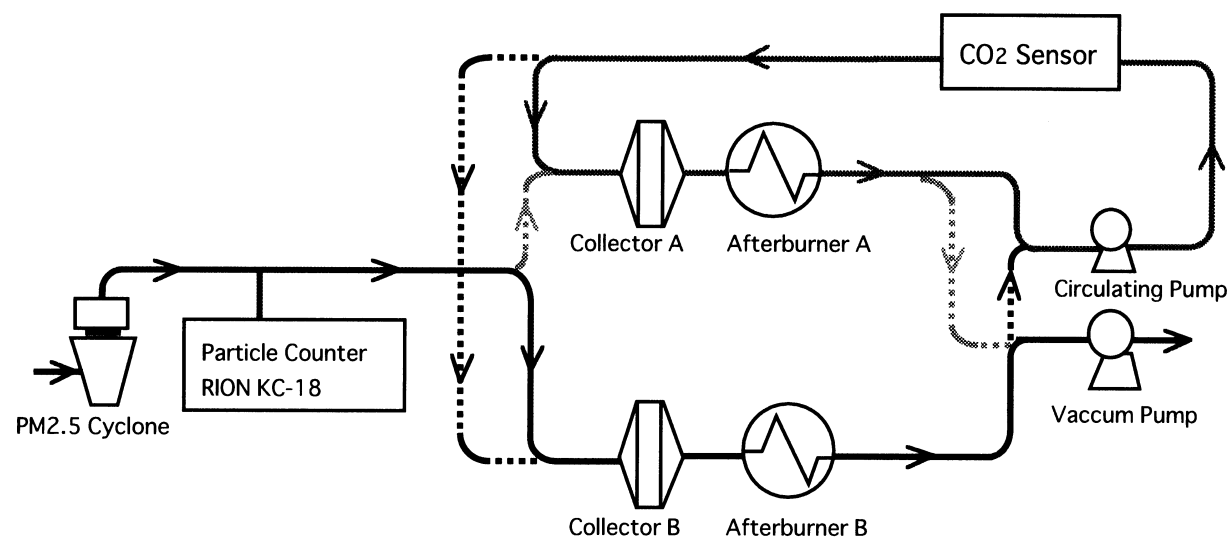

\section{Ambient Carbon \\ Particulate Monitor Flow \\ Schematic}

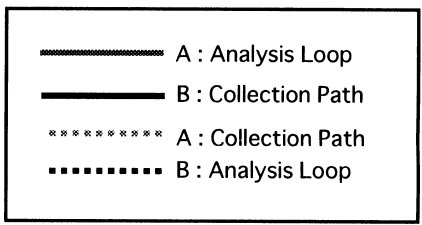

Fig. 3. Schematic diagram of the ambient carbon particulate monitor.

emental carbon are not discussed. A schematic diagram of the carbon monitor is shown in Fig. 3.

Bulk filter samples were collected for every 4 hours by using Whatman 41 filters and a highvolume air sampler $\left(24 \mathrm{~m}^{-3} \mathrm{hr}^{-1}\right)$ located on the front edge of the top deck of the research vessel. Although air sampler was controlled by a wind monitoring system, the pump operated throughout the entire sampling period because of the steady winds (Fig. 2). The filter samples were 
analyzed simultaneously for the major inorganic ions $\left(\mathrm{Na}^{+}, \mathrm{NH}_{4}\right.$, non-sea-salt (nss)- $\mathrm{Ca}^{2+}, \mathrm{Mg}^{2+}, \mathrm{K}^{+}$, $\mathrm{Cl}^{-}, \mathrm{NO}_{3}{ }^{-}, \mathrm{nss}_{-} \mathrm{SO}_{4}{ }^{2-}$ ) by a two channel ion chromatograph system (Dionex, model DX-120).

Number distributions for particles larger than $0.3 \mu \mathrm{m}$ in diameter were measured in 5 size ranges $(0.3-0.5,0.5-1.0,1.0-2.0,2.0-5.0,>5.0 \mu \mathrm{m})$ by an optical particle counter (OPC, Rion, model KC01D) every 20 -min. The flow rate for the OPC was $1.8 \times 10^{-2} \mathrm{~m}^{3} \mathrm{hr}^{-1}$. The particulate volume was calculated for the comparison with the mass concentrations of the chemical substances by using the geometric means for each size range. The particles larger than $2.0 \mu \mathrm{m}$ were not used for the interpretation because of the small numbers of particles of this size observed and the possible loss of particles in the inlet tube. Ozone mixing ratios were measured every 12 -sec by an ozone monitor (Dylec, Model 1150).

\section{RESULTS AND DISCUSSION}

Temporal variation of the concentration of organic aerosol

During the sampling at the station JT, the temporal variation of organic carbon was as shown in Fig. 4. The lowest concentration was $3.3 \mu \mathrm{g} \mathrm{m}^{-3}$ in the beginning of the sampling period, that is 0500 and 0600 , then the concentration increased gradually with time. A concentration peak of 4.5 $\mu \mathrm{g} \mathrm{m}^{-3}$ was observed from 1300 and 1400 of $\mathrm{Au}$ gust 4. A second low concentration interval of 3.6 $\mu \mathrm{g} \mathrm{m}^{-3}$ was recorded during 0300 and 0500 on August 5. At the end of observation period, the concentration was $4.0 \mu \mathrm{g} \mathrm{m}^{-3}$. A smooth temporal variation of a concentration was observed with a concentration difference of $1.2 \mu \mathrm{g} \mathrm{m}^{-3}$ during the 29 -hr period. It is interesting to note that lower values were found before the sunrise and higher values during the daytime.

The values obtained by this cruise tended to be high compared to the concentration levels of less than $1 \mu \mathrm{g} \mathrm{m}^{-3}$ observed during prior cruises in the open Northwest Pacific (Matsumoto et al., 2000). At Cheju Island, south of the Korean peninsula, the mean concentrations of organic carbon with a PM2.5 sampler were reported to be 2.4 $\mu \mathrm{g} \mathrm{m}^{-3}$ (range: $1.3-5.0 \mu \mathrm{g} \mathrm{m}^{-3}$ ) during summer time which is when most air parcels reaching Cheju arrive from the North Pacific (Kim et al., 2000). There is a possibility that certain volatile organic carbon species are trapped by this method, and further comparisons among analytical methods are needed to resolve.

\section{Temporal variation of particle size and number}

From the raw data set of every 20-min. measurement, there was no pronounced spike of parti-

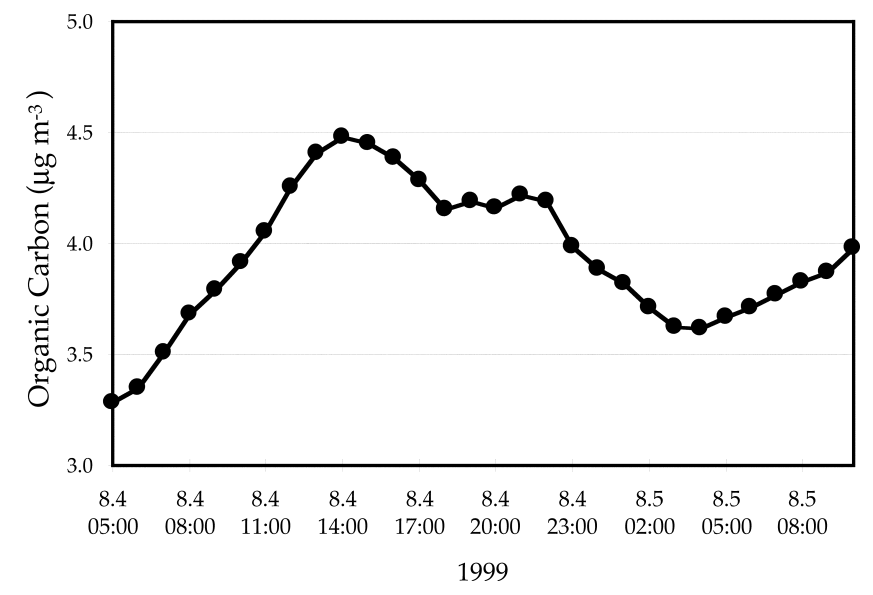

Fig. 4. Temporal variation of the organic carbon concentration at station JT. 
cle number concentration at station JT due to the contamination from the ship itself. To match the sampling times with the carbon measurement, the particle numbers for each size range were averaged over 1-hr intervals. The number concentration for particles from $0.3-0.5 \mu \mathrm{m}$ in diameter decreased dramatically from 33 particles $\mathrm{cm}^{-3}$ to 9.0 particles $\mathrm{cm}^{-3}$ from 1300 and 1400 . In contrast, number of particles larger than $0.5 \mu \mathrm{m}$ increased over this same time period. These values of particles larger than $0.3 \mu \mathrm{m}$ are within the range observed in the latitude band of $20-40^{\circ} \mathrm{N}$ of the western North Pacific (Miura et al., 1996). As discussed below, the temporal variation of the particle density can be explained by changes in organic carbon.

The relationship between particle volume and organic carbon

The particle volumes based on the particle number density are plotted in Fig. 5. The calculated volume for particles 0.3 to $0.5 \mu \mathrm{m}$ were the highest from 1200 and 1300, although those of the other particle size ranges and total volume showed maximum values from 1400 and 1500 . The volume of the $0.3-0.5 \mu \mathrm{m}$ size range was larger than that of the $0.5-1.0 \mu \mathrm{m}$ particles from the beginning of the period to 1500 , then the relative proportions were inverted. There was a pronounced correlation $\left(r^{2}=0.728\right)$ between the mass concentration of organic carbon aerosols and the volume of particles larger than $0.5 \mu \mathrm{m}$ while the correlation with the $0.3-0.5 \mu \mathrm{m}$ particle volume was not significant $\left(r^{2}=0.064\right)$. This result may suggest that organic aerosols are dominant in the particle size larger than $0.5 \mu \mathrm{m}$.

Co-variation of chemical components with different size particles

The mean concentrations of the major components at the station JT during the stationary observation period are summarized in Table 1. The concentrations of the major inorganic ions were within the background levels of the typical MBL over the North Pacific (Prospero et al., 1985; Uematsu et al., 1995). To examine the relation-

Table 1. Mean concentrations of $\mathrm{ma}$ jor aerosol components $\left(\mu \mathrm{g} \mathrm{m}^{-3}\right)$

\begin{tabular}{lll}
\hline Constituent & Mean \pm s.d. & Range \\
\hline $\mathrm{Na}^{+}$ & $4.7 \pm 0.3$ & $(4.3-5.3)$ \\
$\mathrm{NH}_{4}{ }^{+}$ & $0.19 \pm 0.05$ & $(0.13-0.28)$ \\
nss-Ca $^{2+}$ & $0.20 \pm 0.05$ & $(0.12-0.25)$ \\
${\text { nss- } \mathrm{SO}_{4}{ }^{2-}}^{0.45 \pm 0.14}$ & $(0.31-0.65)$ \\
Org C & $3.9 \pm 0.3$ & $(3.3-4.5)$ \\
\hline
\end{tabular}

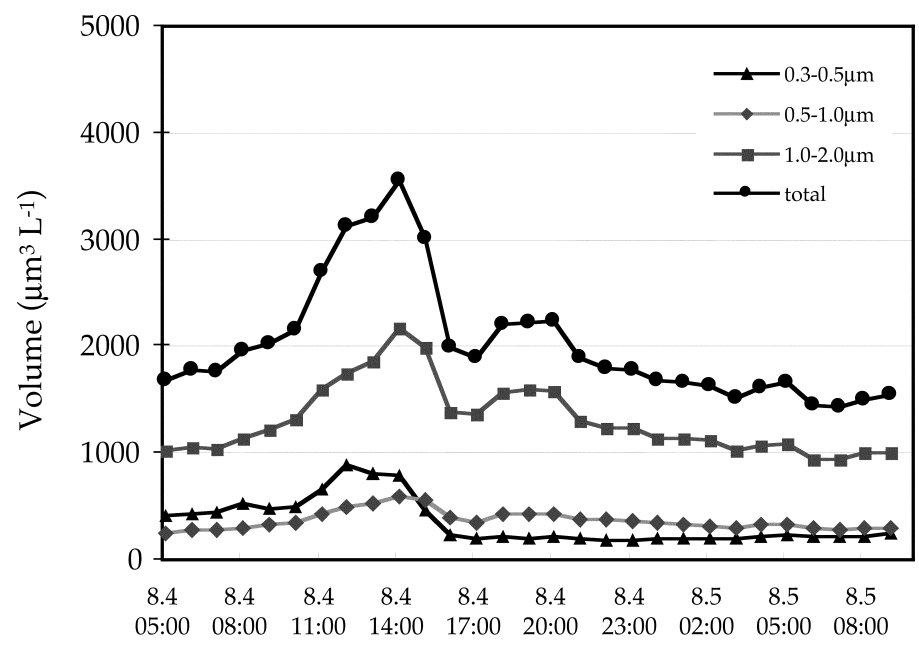

1999

Fig. 5. Temporal variation of the 1-hr averaged particle volume by particle size. 


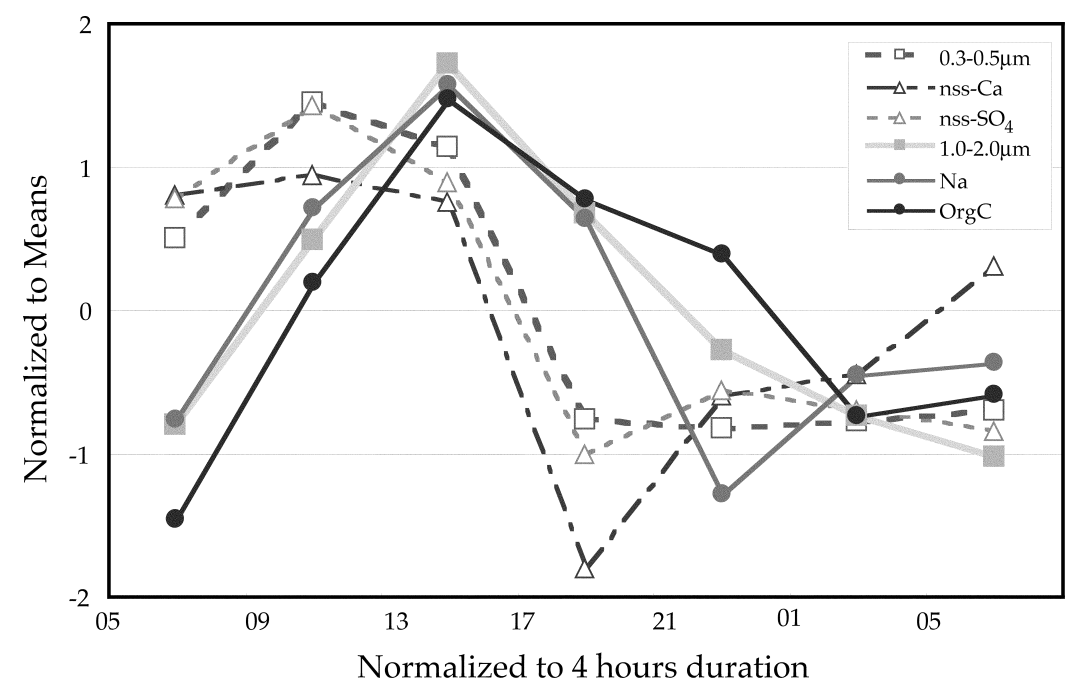

Fig. 6. The relative variation of $\mathrm{Na}^{+}, n s s-\mathrm{Ca}^{2+}, \mathrm{nss}^{-} \mathrm{SO}_{4}{ }^{2-}$, $\mathrm{Org} \mathrm{C}$, particle volumes of 0.3 to $0.5 \mu \mathrm{m}$ and 1.0 to 2.0 $\mu m$ at station $J T$.

ship and variations among these chemical substances, the 4-hr concentrations $(X)$ were converted to standard normal variables $(Z)$ by the mean value $(\mu)$ and the standard deviation $(\sigma)$ as follows:

$$
Z=(X-\mu) / \sigma .
$$

The relative variations among $\mathrm{Na}^{+}, \mathrm{nss}-\mathrm{Ca}^{2+}$, nss- $\mathrm{SO}_{4}{ }^{2-}$, Org C, particle volumes of $0.3-0.5 \mu \mathrm{m}$ and $1.0-2.0 \mu \mathrm{m}$ are shown in Fig. 6. Two pronounced groups were identified and these were related to particle size. The first group, that is, nss- $\mathrm{Ca}^{2+}$ and nss- $\mathrm{SO}_{4}{ }^{2-}$ was tracked the changes in the volume of the $0.3-0.5 \mu \mathrm{m}$ particles. High relative concentrations of nss- $\mathrm{Ca}^{2+}$ and nss- $\mathrm{SO}_{4}{ }^{2-}$ lasted from 0500 to 1700 , then the concentrations were decreased rather steady to the end of the observation period on 5 August. This pattern and the fact that typical sea-salt elements displayed a different pattern suggest that aerosols in the size range of $0.3-0.5 \mu \mathrm{m}$ are dominated by particles other than sea salt. The concentration of nss- $\mathrm{Ca}^{2+}$ $\left(0.12-0.25 \mu \mathrm{g} \mathrm{m}^{-3}\right)$ was within the range of background levels in the remote marine atmosphere (Suzuki and Tsunogai, 1988). Nss-Ca ${ }^{2+}$ is often considered an indicator of mineral aerosols with mass median diameters of a few micrometers. The difference between the observed and expected size distribution of nss- $\mathrm{Ca}^{2+}$ can be explained if most of the large Ca-bearing particles from land sources were removed during transport. The co-variation between $\mathrm{nss}-\mathrm{Ca}^{2+}$ and nss- $\mathrm{SO}_{4}{ }^{2-}$ may have originated from processes, such as the conversion of $\mathrm{CaCO}_{3}$ to $\mathrm{CaSO}_{4}$, but mixing of air masses during transport and the possible contribution of nss$\mathrm{SO}_{4}{ }^{2-}$ generated gas-to-particle conversion from marine biological sources cannot be discounted.

For the second group, the variation of $\mathrm{Na}^{+}$and organic carbon were correlated with that of the volume of 1.0-2.0 $\mu \mathrm{m}$ particles. The highest concentration peaks for this group were found between 1300 and 1700. The temporal patterns of organic carbon particles therefore mirror those of sea salt, which has larger mass median diameter than most other non-sea salt components (i.e., nss$\mathrm{Ca}^{2+}$ and nss- $\mathrm{SO}_{4}{ }^{2-}$ ). The concentration of $\mathrm{Na}^{+}$was obtained from the bulk filter samples, while that of organic carbon was determined after particles larger than $2.5 \mu \mathrm{m}$ were removed. The air inlet for the measurement system was equipped with a particle counter. Thus, similar variations among three components were made apparent by three different techniques during the same period. 


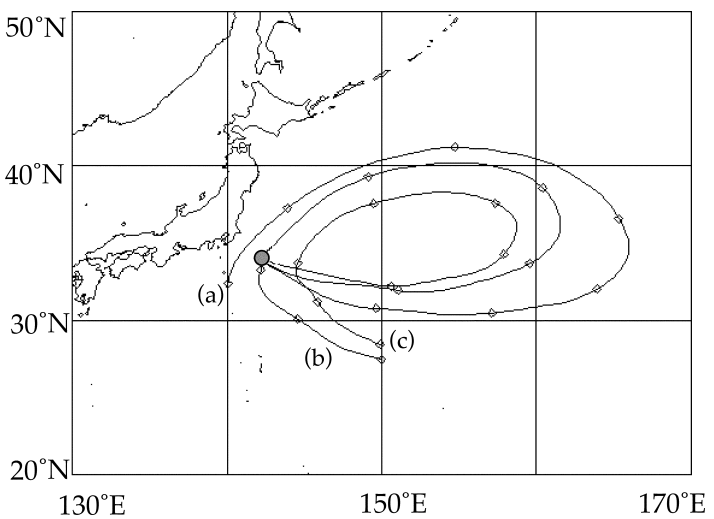

Fig. 7. Seven-day isentropic back air trajectories at the altitude of $500 \mathrm{~m}$ from station JT during the observation period: (a) 0900, (b) 2100 on 4 August and (c) 0900 on 5 August (JST).

History and several features of the air masses sampled

Seven-day isentropic air trajectories at an altitude of $500 \mathrm{~m}, 1000 \mathrm{~m}$ and $1500 \mathrm{~m}$ were calculated backwards in time from the station JT for the observation period, that is, 0900, 2100 on 4 August and 0900 on 5 August. The trajectories at an altitude of $500 \mathrm{~m}$ (Fig. 7) indicated that the air sampled passed over the Japanese islands, but it took at least 4 or 5 days to reach the R/V Tansei Maru and traveled over $5000 \mathrm{~km}$ below $1800 \mathrm{~m}$ height. These stable airflow conditions lasted throughout the entire observation period. There was no clear relationship between the concentration of sea-salt aerosol and the wind speed, presumably because the winds were fairly constant during the observation period. The average ozone concentration was $14 \pm 2 \mathrm{ppb}$, a value comparable to background levels in the marine atmosphere of the mid-latitudes over the North Pacific (Nagao et al., 1999).

The concentration peaks of nss- $\mathrm{Ca}^{2+}$ and nss$\mathrm{SO}_{4}{ }^{2-}$ observed between 0500 and 1700 may have been caused a large-scale loop transport of substances from land with several days. This temporal variation of these two substances was within the range of the background concentration levels in the typical marine atmosphere. Only fine parti- cles smaller than $0.5 \mu \mathrm{m}$ could survive during transport in the MBL.

\section{Possible sources of organic aerosols}

Based on the temporal variation of organic aerosol and its correlation with the size fraction larger than $0.5 \mu \mathrm{m}$, the mass median diameter of organic aerosol apparently was larger than $0.5 \mu \mathrm{m}$. Furthermore the trends in organic aerosols were similar to those of sea-salt particles. It has been shown that large sea-salt particles containing substantial amounts of organic carbon can be generated from organic-enriched seawater via rupture of the micro layer by bursting bubbles (Wallace and Duce, 1978). Even if organic aerosols smaller than $0.5 \mu \mathrm{m}$ were produced from the sea surface through the gas-to-particle conversion processes, that contribution to the mass concentration likely would be rather small because of its size during this 29-hr field experiment. Diurnal variations of organic carbon concentrations, that is high concentrations in daytime and low concentrations at night, were observed over the northern North $\mathrm{Pa}$ cific and its marginal seas in a previous study (Matsumoto et al., submitted). Diurnal variations in the MBL thickness may cause the diurnal variations of aerosol concentrations (Mari et al., 1998), but if this occurred at the station JT, various types of aerosols including non-sea-salt components would have changed together. As this was not observed, factors other than the MBL thickness, such as variations in source strengths or removal, presumably lead to the occurrence of the two groups of substances observed.

It has been suggested that the main source of marine organic aerosols is the continents (Cachier et al., 1986). However, our study at the station JT indicates that marine environment also can supply significant amounts of organic carbon to the atmosphere. Indeed, organic substances from oceanic micro layer may be recycling between atmosphere and sea surface, and this may also involve substances of continental origin. To obtain more quantitative results with respect to the effects of marine biological activity, it will be necessary to investigate the temporal variations of organic aero- 
sols and number of particles over regions with various primary production rates.

Acknowledgments-We are grateful to Captain K. Namba, the officers and crew of the R/V Tansei-Maru and the graduate students from the ORI for their collaboration and assistance during the cruise. We would like to thank Dr. R. Arimoto, New Mexico State University, for his critical reading of the manuscript. This research was partially supported by Grant-in-Aid for General Scientific Research, the Ministry of Education, Science, Sports and Culture, Japan and CREST of Japan Science and Technology.

\section{REFERENCES}

Cachier, H., Buat-Menard, P., Fontugne, M. and Chesselet, R. (1986) Long-range transport of continentally-derived particulate carbon in the marine atmosphere: evidence from stable carbon isotope studies. Tellus 38B, 161-177.

Charlson, R. J., Langner, J., Rodhe, H., Leovy, C. B. and Warren, S. G. (1991) Perturbation of the Northern Hemisphere radiative balance by backscattering from anthropogenic sulfate aerosols. Tellus $\mathbf{4 3 A B}$, 152-163.

Chylek, P., Lesins, B., Vidden, G., Wong, J. G. D., Pinnick, R. G., Ngo, D. and Klett, J. D. (1996) Black carbon and absorption solar radiation by clouds. $J$. Geophys. Res. 101, 23,365-23,371.

Gundel, L. A., Dod, R. L., Rosen, H. and Novakov, T. (1984) The relationship between optical attenuation and black carbon concentration for ambient and source particles. Sci. Total Environ. 36, 197-202.

Hoffman, E. J. and Duce, R. A. (1977) Organic carbon in marine atmospheric particulate matter: concentration and particle size distribution. Geophys. Res. Lett. 4, 449-452.

Kim, Y. P., Moon, K.-C. and Lee, J. H. (2000) Organic and elemental carbon in fine particles at Kosan, Korea. Atmos. Environ. 34, 3309-3317.

Mari, C., Suhre, K., Bates, T. S., Johnson, J. E., Rosset, R., Bandy, A. R., Eisele, F. L., Mouldin, R. L., III and Thornton, D. C. (1998) Physico-chemical modeling of the First Aerosol Characterization Experiment (ACE 1) Lagrangian B: 2. DMS emission, transport and oxidation at the mesoscale. J. Geophys. Res. 103, 16457-16473.

Matsumoto, K., Tanaka, H., Nagao, I. and Ishizaka, Y. (1997) Contribution of particulate sulfate and organic carbon to cloud condensation nuclei in the marine atmosphere. Geophys. Res. Lett. 24, 655-658.

Matsumoto, K., Nagao, I., Tanaka, H., Miyaji, H.,
Iida, T. and Ikebe, Y. (1998) Seasonal characteristics of organic and inorganic species and their size distributions in atmospheric aerosols over the Northwest Pacific Ocean. Atmos. Environ. 32, 1931-1946.

Matsumoto, K., Uematsu, M. and Mukai, H. (2000) Measurement of carbonaceous aerosols in the marine atmosphere over the North Pacific Ocean. Atmos. Environ. (submitted).

Miura, K., Nakae, S., Matsuda, K., Tsuge, N. and Aoki, K. (1996) Size distribution of aerosol particles over the western Pacific Ocean and the Southern Ocean. Proc. NIPR Symp. Polar Meteorol. Glaciol. 10, 102110.

Murphy, D. M., Anderson, J. R., Quimm, P. K., Mclnnes, L. M., Brechtel, F. J., Kreidenweis, S. M., Middlebrook, A. M., Posfai, M., Thomson, D. S. and Buseck, P. R. (1998) Influence of sea-salt on aerosol radiative properties in the Southern Ocean marine boundary layer. Nature 392, 62-65.

Nagao, I., Matsumoto, K. and Tanaka, H. (1999) Characteristics of dimethylsulfide, ozone, aerosols, and cloud condensation nuclei in air masses over the northwestern Pacific Ocean. J. Geophys. Res. 104, 11675-11693.

Novakov, T. and Penner, J. E. (1993) Large contribution of organic aerosols to cloud-condensation nuclei concentrations. Nature 365, 823-827.

Novakov, T., Corrigan, C. E., Penner, J. E., Chuang, C. C., Rosario, O. and Mayol Bracero, O. L. (1997) Organic aerosols in the Caribbean trade winds: A natural source? J. Geophys. Res. 102, 21307-21313.

Prospero, J. M., Savoie, D. L. and Nees, R. T. (1985) Particulate sulfate and nitrate in the boundary layer over the North Pacific Ocean. J. Geophys. Res. 90, 10586-10596.

Rivera-Carpio, C. A., Corrgan, C. E. and Novakov, T. (1996) Derivation of contributions of sulfate and carbonaceous aerosols to cloud condensation nuclei from mass size distributions. J. Geophys. Res. 101, 19483-19493.

Sokolik, I. N. and Toon, O. B. (1999) Incorporation of mineralogical composition into models of the radiative properties of mineral aerosol from UV to IR wavelengths. J. Geophys. Res. 104, 9423-9444.

Suzuki, T. and Tsunogai, S. (1988) Origin of calcium in aerosols over the western North Pacific. J. Atmos. Chem. 6, 363-374.

Takemura, T., Okamoto, H., Maruyama, Y., Numaguchi, A., Higurashi, A. and Nakajima, T. (2000) Global three-dimensional simulation of aerosol optical thickness distribution of various origins. J. Geophys. Res. 105, 17853-17873.

Uematsu, M. (1998) Distribution and characterization of Asian aerosols over the Western North Pacific re- 
gion. Global Environ. Res. 2, 39-45.

Uematsu, M., Kawamura, K., Ibusuki, T. and Kimoto, T. (1995) Chemical composition of marine aerosols over the Central North Pacific-Results from the 1991 cruise of Hakurei Maru No. 2-. Biogeochemical Processes and Ocean Flux in the
Western Pacific (Sakai, H. and Nozaki, Y., eds.), 3 14, Terra Sci. Pub. Co., Tokyo.

Wallace, G. T. and Duce, R. A. (1978) Transport of particulate organic matter by bubbles in marine waters. Limnol. Oceanogr. 23, 1155-1167. 